\title{
Growth Strategies in the Sugarcane Sector: A Relationship between Macro-Environmental Variables and Movements of Strategic Growth
}

\author{
Thiago Abboud Campaz
}

FG/AGRO

Av. Costábile Romano, 2926 - sala 10 - Ribeirão Preto - SP - Brazil - zip code 14096-275

Tel: 55-16-3913-4871 E-mail: thiago.campaz@fga.com.br / thiagocampaz@gmail.com

Perla Calil Pongeluppe Wadhy Rebehy

FEARP/USP

Av. Carlos Consoni, 1100 - hs 72 - Ribeirão Preto - SP - Brazil - zip code 14024-270

Tel: 55-16-3602-3903 E-mail: perla@usp.br

Matheus Alberto Consoli

MARKESTRAT - Centro de Pesquisa e Projetos em Marketing \& Estratégia

Rua Maestro Ignácio Stábile, 520 - Ribeirão Preto - SP - Brazil, zip code 14025-640

Tel: 55-16-3456-5555Ｅ-mail: consoli@markestrat.org

\author{
Carlos Alberto Gabrieli Barreto Campello \\ FEARP/USP \\ Av. Bandeirantes, 3900 - Ribeirão Preto - SP \\ E-mail: campello@fearp.usp.br
}

Received: August 20, 2017

doi:10.5296/jmr.v10i1.11728
Accepted: Nov. 16, $2017 \quad$ Published: January 1, 2018

URL: https://doi.org/10.5296/jmr.v10i1.11728 


\begin{abstract}
The sugarcane sector has been gaining more importance in both Brazilian and World economies, even though it has had a lack of agricultural investments and climate issues has generated questionings about the future of the sector. To analyse this trend, the present work was based on the following growth strategies: internal growth, horizontal integration, diversification, and vertical integration. The objective of the present research is to assess the relationship between these types of strategies and macro-environmental variables in order to determine any possible correlation. Bibliographic and documental survey on the behaviour of macro-environment variables was carried out. The Pearson's correlation test was used to identify the relationship between these variables and growth strategies. It was possible to observe that each type of growth strategy is related to one specific type of variable, which is exclusive to each strategy, except in the case of diversification. That is, electric energy prices have a correlation with internal growth and the real growth rate is correlated with horizontal growth. None of these macro-environmental variables repeated in other growth strategies. The only exception was the diversification strategy, which was correlated with eight variables, with five of these being exclusive to this type of strategy.
\end{abstract}

Keywords: Sugarcane sector, Growth strategy, Analysis of external environment 


\section{Introduction}

Brazil is the leading producer of sugarcane, accounting for more than 45 percent of the total amount produced in the world, and the second greatest producer of ethanol, only trailing the United States, whose ethanol is primarily produced from corn (Food and Agricultural Organization of the United Nations [FAO], 2012; United States Department of Agriculture [USDA], 2012). The functional multiplicity of the sugarcane, the search for renewable fuels, the growing demand for sugar, among other reasons, have recently been perceived by the agents of the sector as well as by those interested in this type of business (Neves \& Conejero, 2010).

The importance of the sugarcane complex is reflected on the 2011/12 crop, whose activities represented 2 percent of the GNP, moving US\$ 30 billion and generating approximately 4.5 million jobs directly and indirectly after growing 10 percent a year since 2000 (ProCana, 2012).

The country has a good performance in virtually the entire production cycle of sugar and ethanol, from the cultivation to the installation of equipment at the mills, including distribution to the final consumers, compared to other producer countries (União da Indústria da Cana-de-Açúcar [UNICA], 2011a).

The sugarcane industry showed strong evolution in the last decade in Brazil, with 120 new projects. This increase was boosted by the good perspectives for ethanol, mainly because of the domestic demand resulting from the success of flex-fuel cars, end of fuel subsidies in the USA, and transformation of ethanol into an international commodity (Zafalon, 2011).

However, this sectorial growth was interrupted in 2008 because of the global financial crisis. A company's strategy growth, which was then the result of the construction of new units and expansion of production capacity, has now occurred by means of mergers and acquisitions. This caused the growth in the sector following the 2008/09 crop to be of 3 percent per year until the 2011/12 crop, when there was a reduction in the sugarcane production in the country (Jank, 2011).

With the aggravating financial situation of the mills caused by the 2008 crisis, there was also an elevation of production costs, maintenance of the gasoline prices, and severe climate problems, all contributing to the increased debts among the companies and to the uncertainty about the growth strategy in the sector for the next years (Canaplan, 2012).

According to the Itaú BBA (2012), with all these problems faced by the majority of the sector groups, mergers and acquisitions were the solution found by most of them. As a result, the new entrants had the chance to have assets in the sugarcane sector. This wave of mergers and acquisitions has caused the consolidation of the sector and changed the profile of the companies who were leading the sector. In the 2005/06 crop, the five major players were traditional Brazilian groups, meaning 100-percent national capital, whereas in the 2011/12 crop, one can observe the presence of oil companies and trading organisations, mainly international ones, in the shareholding framework of the companies. 
Gryubisich (2012) states that the future perspectives for the sector are positive. To understand the growing demand for the flex-fuel cars and the rising global consumption of sugar, the Brazil's sugarcane production needs to double to 1.2 billion tons in the next ten years. This shows that the sectorial growth is essential for the continuity of the sugar and ethanol market, but to expand the production capacity, it is needed to define public policies so that the sector can be attractive again and lead the companies to invest (Gryubisich, 2012).

The macro-environment variables reach the sectorial growth so that changes in these variables make the companies opt for different strategies to grow, such as vertical and horizontal integrations, diversifications, and internal growth (Wright, Kroll, \& Parnell, 2000).

Companies have no direct control of the macro-environment segments and element, such as demographic, technological, economic, political-legal, and social. In this way, the information needed to understand each aspect and its implications for definition and implementation of adequate strategies should be collected (Hitt, Ireland, \& Hoskisson, 2008). Therefore, the understanding of the main variables influencing the growth of the sector and how they influence the strategies adopted by the companies is essential in terms of industrial planning.

Consequently, the objective of this research is to identify the existing relationship between macro-environmental variables and the occurrence of each growth strategy adopted by the sugarcane sector companies. In order to achieve such an objective, it will be necessary: i) to identify the main growth strategies of each company in the sugarcane sector from 2005 to 2011 ; ii) to map the behaviour of external environment variables influencing the sector from 2005 to 2011; and iii) to identify which are the mains points of the external environment influencing the occurrence of each growth strategy.

\section{Methodology}

The present research was characterised as being both bibliographic and documental. The approach is divided into qualitative and quantitative. The qualitative step consisted of: i) to identify peculiarities inherent to the sugarcane sector; ii) to map and analyse growth strategies of each company, and iii) to choose and analyse macro-environmental variables to be further studied in the quantitative step.

The quantitative step was conducted by using statistics software SPSS ${ }^{\circledR} 20$ and STATA $® 9.2$ for description and explanation of the phenomena.

Also, in the quantitative step, it was chosen to perform a correlation test between macro-environmental variables and each growth strategy in order to understand whether there is some type of statistical relationship.

To choose the statistic test, the normal distribution of the variables was assessed. Therefore, it was chosen to apply the Kolmogorov-Smirnov test, whose null hypothesis points to normal distribution indicating which method should be used. By means of the test described, it was observed that both macro-environmental variables and occurrence of growth strategies met the hypothesis of normality. 
Due to the result of the normality test, the analysis of correlation was based on the Pearson's correlation test, which represents the measurement of the degree of association between two variables from a series of observations.

The steps of the research are demonstrated in the Table 1 bellow:

Table 1. Steps of the Research

\begin{tabular}{|c|c|c|}
\hline Steps & Objective & Procedure \\
\hline $\begin{array}{l}\text { 1. Bibliographic survey with } \\
\text { deductive method }\end{array}$ & $\begin{array}{l}\text { To identify growth strategies } \\
\text { in the sugarcane sector and } \\
\text { macro-environment variables } \\
\text { that might influence the } \\
\text { occurrence of them. }\end{array}$ & $\begin{array}{l}\text { To gather primary and } \\
\text { secondary data from books, } \\
\text { articles, thesis, websites, } \\
\text { journals, periodicals, } \\
\text { magazines, communications, } \\
\text { presentations, among others. }\end{array}$ \\
\hline 2. Documental research & $\begin{array}{l}2 \mathrm{a} \text {. To map and classify the } \\
\text { main interactions between } \\
\text { companies that went through } \\
\text { restructuring process to grow } \\
\text { in the sector between } 2005 \\
\text { and } 2011 \text {. } \\
2 \mathrm{~b} \text {. To survey the evolution } \\
\text { of macro-environmental } \\
\text { variables (defined in the first } \\
\text { step) from } 2005 \text { to } 2011 \text {. }\end{array}$ & $\begin{array}{l}\text { This information was } \\
\text { obtained by means of books, } \\
\text { articles, theses, websites, } \\
\text { periodicals, journals, } \\
\text { communications, } \\
\text { presentations, among others. }\end{array}$ \\
\hline $\begin{array}{l}\text { 3. Statistical analysis } \\
\text { (correlation) }\end{array}$ & $\begin{array}{l}\text { To understand the } \\
\text { relationship between } \\
\text { macro-environmental } \\
\text { variables and growth } \\
\text { strategies over the years. }\end{array}$ & \\
\hline
\end{tabular}

\section{Description of the Results}

According to Neves and Conejero (2010), there were great investments in the sugarcane industry in the recent years aiming to expand the production capacity, improve productivity, delivery, stocking, and logistics, and develop new products.

Much of the investments made by such companies were mostly aimed at growth. The forms of implementation of this growth can be divided into four fronts: internal growth, horizontal integration, diversification, and vertical integration.

In the present study, one opted for considering only those strategies involving the interaction between one or more companies in terms of vertical and horizontal integrations and diversification, highlighting mergers and acquisitions as well as strategic alliances. These 
strategies are shown in Figure 1. The strategy of internal growth is represented by the increase in production capacity (\%) in production capacity (\%) in Figure 2.

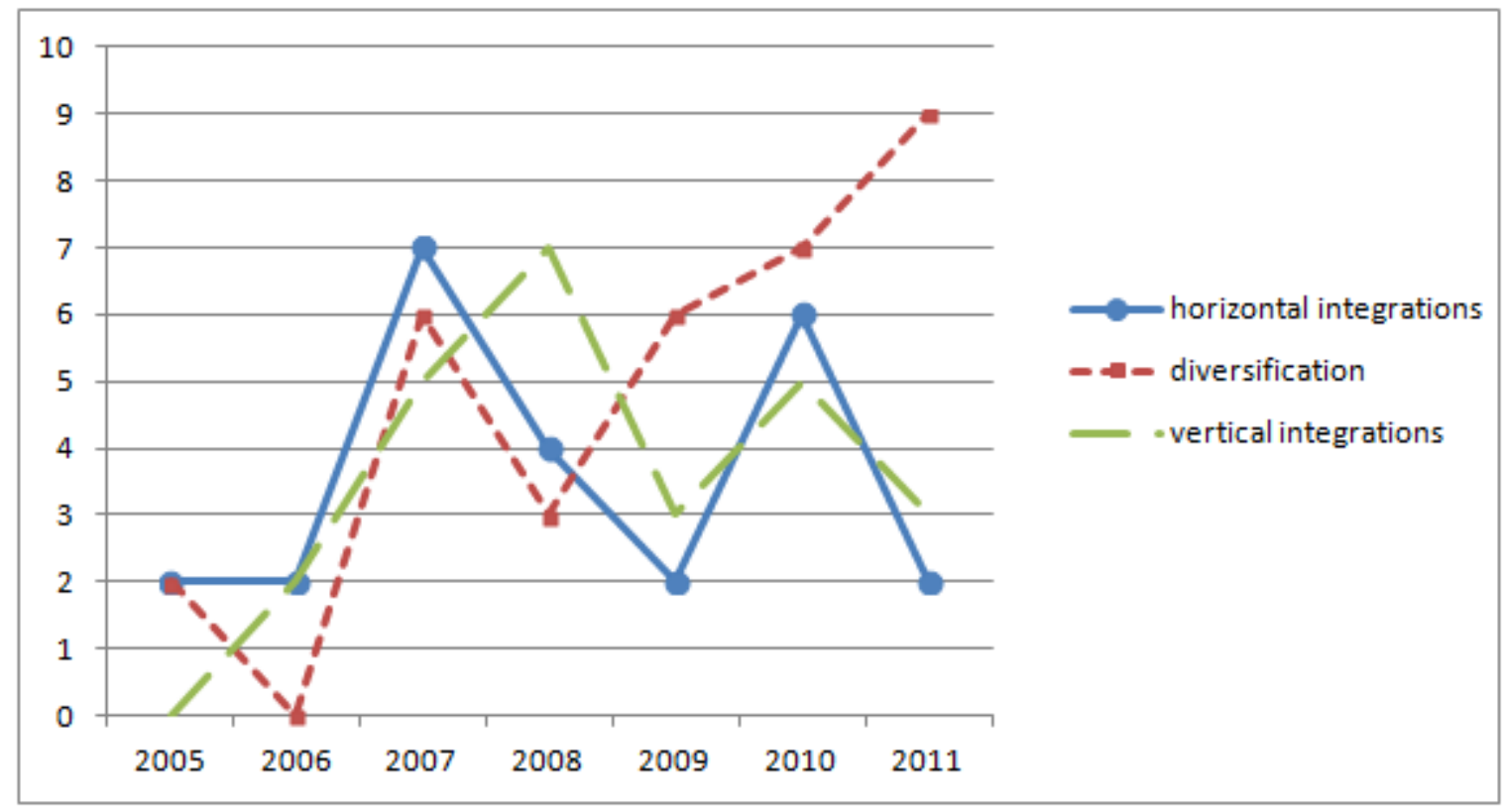

Source: Websites of the companies (2012), FG/AGRO (2011), Neves and Conejero (2010)

Figure 1. Number of cases of horizontal integration, diversification, and vertical integration

\section{Horizontal Integration}

Horizontal integration occurs when a company acquires one or more similar companies in order to grow, with all operating at the same level in the production chain (Pearce \& Robinson, 2005).

The main reason for using this strategy is to increase the participation of the companies in the market, followed by increase in revenues, which give them more bargaining power to negotiate with suppliers and clients so that costs can be reduced by means of scale economy. Moreover, a large size allows the company to promote its products and services even more efficiently for more people and to have more flexibility and access to distribution canals (Wright et al., 2000).

From 2005 to 2011, 25 occurrences of mergers and acquisitions or strategic alliances with horizontal integration were observed recorded, as can be seen in Figure 1.

\section{Diversification}

The strategy of diversifications aims to increase the value of the company and improve its performance by increasing strengths and opportunities and decreasing weaknesses and exposure to business risks. Diversification can also neutralise or even reduce the value of a company when it neutralises the competitor's power at the expense to its own power or when there is an increase in the costs with managerial salaries (Hitt et al., 2008). 
According to Pearce and Robinson (2005), diversification can occur concentrically or through conglomerates. The difference is that the former involves acquisition or development of a business related to the company's current business in terms of technology, market or products, whereas the latter does not.

A movement in this sense is the entrance of companies operating in other activities in order to diversify and aggregate values to their business. Many of these companies associate with traditional sugarcane groups, whereas others prefer to build their own business. In general, these types of movements characterise diversifications as conglomerates, whose main goal is the financial investment.

The concentric diversification is present in those cases in which companies seek to produce other by-products from the sugarcane otherwise ethanol, sugar, and electric energy in order to reduce risks and increase portfolio and profit margins.

Between 2005 and 2011, 33 occurrences of mergers and acquisitions or strategic alliances were mapped and characterised as diversification (Figure 1).

\section{Vertical Integration}

According to Hitt, Ireland, and Hoskisson (2008), vertical integration occurs when a company produces its own inputs (backwards integration) or has its own source of product distribution (forwards integration).

The main reason for the backwards vertical integration is the desire to increase the reliability in delivery or quality of the raw material used in the production. This desire is particularly good when the number of suppliers is small and the number of competitors is high. The forwards vertical integration is indicated in those cases in which one wants to increase the production stability (Pearce \& Robinson, 2005).

In the sector in question, many sugar trading companies have opted for acquiring sugarcane mills in order to increase their profit margins and obtain more confidence in the delivery of this input.

From 2005 and 2011, 25 occurrences of mergers and acquisitions or strategic alliances were conducted and characterised as vertical integration, as can be seen in Figure 1.

\section{Internal Growth}

Internal growth is achieved by increasing the production capacity, sales, workforce, among others. Companies believe that internal growth preserves the organisational culture, including quality, efficacy and image. Another relevant factor is that costs with internal growth are normally smaller than those with acquisition (Wright et al., 2000).

Due to the peculiarities inherent to the sector, one opted for analysing internal growth based on the increase in production capacity. In sugarcane mills, this factor is mainly influenced by two variables: industrial capacity and agricultural capacity. The industrial capacity can be increased by expanding the existing plants (brownfields) and constructing new ones (greenfileds). 
Therefore, to measure the internal growth of the Brazilian sugarcane industry, one opted for analysing the variation in the total amount of sugarcane processed in Brazil from 2005/06 to 2011/12. During this period of time, the mean annual growth was of $5.2 \%$ in the sector, that is, shifting from 387.35 million tons in the 2005/06 crop to 550.09 million tons in the $2011 / 12$ crop. The maximum production observed in this period was of 620.13 million tons in the 2010/11 crop, as can be seen in Figure 1.

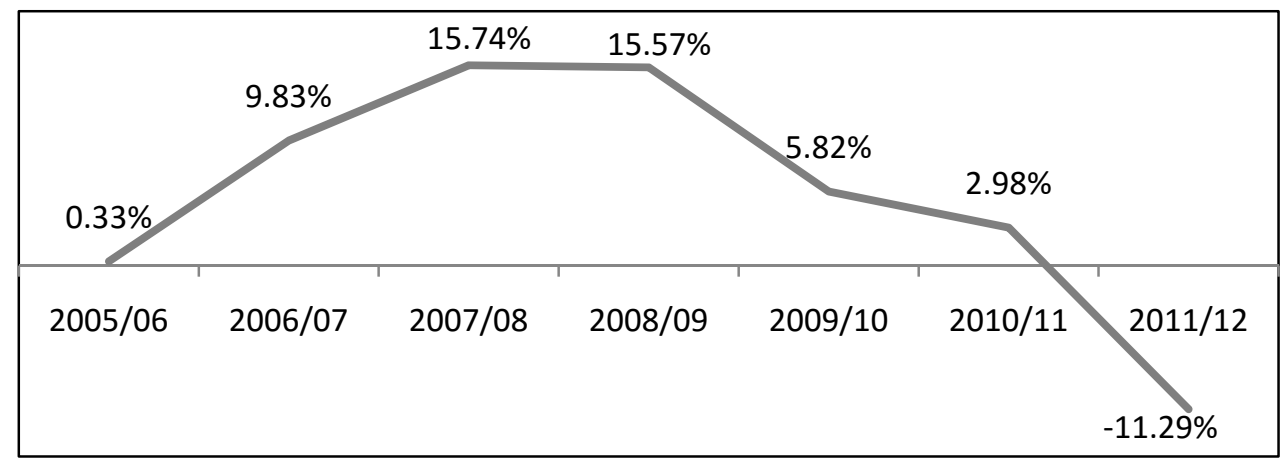

Source: UNICA $(2011, a)$.

Figure 2. Internal growth in the sugarcane sector

\section{Analysis of External Environment in the Sugarcane Sector}

In this step, the main variables of the external environment influencing the sugarcane sector will be analysed, as shown in Table 2 . The objective is to justify the choice of each variable and demonstrate its relation to the sector, including an analysis of the historical behaviour of the sector during the period between 2005 and 2011.

Table 2. Macro-environmental variables in sugarcane industry

\begin{tabular}{|c|c|c|}
\hline Variables & Source & Relationship with growth strategies \\
\hline \multicolumn{3}{|l|}{ Demographics } \\
\hline Population & FMI, BNDES & $\begin{array}{l}\text { - Sugar demand is related to population's increase } \\
\text { - Ethanol and electricity are important options of } \\
\text { renewable energy to support population's } \\
\text { growth in a sustainable way }\end{array}$ \\
\hline $\begin{array}{l}\text { GNP per capita } \\
\text { (US\$) }\end{array}$ & Santander & $\begin{array}{l}\text { - Increases in this index implies in changes in } \\
\text { demand for sugarcane products }\end{array}$ \\
\hline Land availability & $\begin{array}{l}\text { Embrapa, Canasat, } \\
\text { CNPS }\end{array}$ & $\begin{array}{l}\text { - The sugarcane cultivation depends on land } \\
\text { availability }\end{array}$ \\
\hline \multicolumn{3}{|l|}{ Economic } \\
\hline Real growth rate & Santander & $\begin{array}{l}\text { - Consumption of sugarcane sub products tends to } \\
\text { be higher in years that a country presents a real } \\
\text { growth rate. }\end{array}$ \\
\hline $\begin{array}{l}\text { SELIC Interest } \\
\text { rates }\end{array}$ & $\begin{array}{l}\text { Santander, Banco } \\
\quad \text { Central }\end{array}$ & $\begin{array}{l}\text { - Interest rate changes affect directly decisions } \\
\text { such as investments, financing, prices and }\end{array}$ \\
\hline
\end{tabular}




\section{Macrothink Minstitute}

Credit availability

BNDES

Exchange rate

Santander

Sugar prices

ICE

Oil prices

Santander

Electric energy

CCEE

prices

purchase

- Harvesting and prices are cyclical in sugarcane industry, requiring companies strengthen their working capital structure and liquidity level

- Investments amounts required by expansion projects or acquisitions are very high

- Variances in exchange rate influence the economy in activities like exports, financing and purchase

- There is a high negative correlation between sugar prices (NY\#11) and exchange rate (R\$/US\$)

- Increase in oil prices is reflected on the gasoline's price, which exerts a "ceiling" price for hydrated ethanol

- Mills have realized the benefits of selling electricity and started investing in projects to make it feasible

\section{Political-legal}

Gasoline prices

ANP

- Used as inflation control tool by government, this variable affects the financial performance of Petrobras and discourage ethanol's production

\section{Social}

Mechanised crop

ANP

- Increases in mechanization level, have reduced precarious working conditions levels in the sector and the emission of $\mathrm{CO}^{2}$

\section{Technological}

New products

João, Porto, Galina

- Product diversification allows mills to reduce their risks and increase their margins

Productivity

Banco Pine

- Shows evolutions in soil usage, sugarcane varieties, mechanization effectiveness, plague control, among others.

\section{Demographic Factors}

The main factors regarding the demographic environment are the following: population size, age structure, geographic distribution, ethnic mixture, and income distribution (Hitt et al., 2008).

Kotler and Keller (2006) state that demographic trends are reliable indicators in both shortand medium-terms. 


\section{Population}

The growth of world's population has been discussed and generated concerns. This fact and the excessive consumption can result in lack of food, exhaustion of ore deposits, super-population, excess of residues, pollution, among other aspects (Kotler \& Keller, 2006).

This demographic variable influences directly the sugarcane industry. In the case of sugar, which is a primary consumption product, its demand is closely related to the number of inhabitants. On the other hand, ethanol and sugarcane bagasse electricity, emerge as important alternatives of renewable energy to support the population growth in a sustainable way.

According to IMF data (Fundo Monetário Internacional, 2012), the Brazil's population increased from 184.18 million in 2005 to 194.93 million people in 2011, meaning a growth of 0.9 percent a year. The evolution of the Brazilian population during this period can be seen in Figure 3.

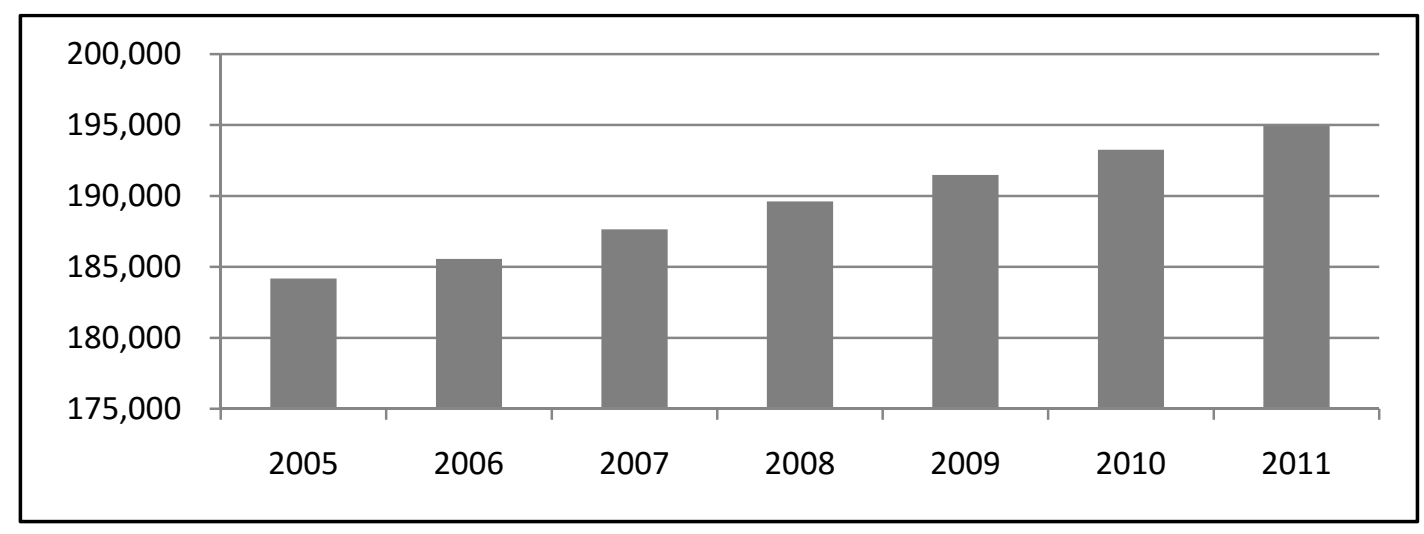

Source: IMF (Fundo Monetário Internacional, 2012)

Figure 3. Brazilian population (thousands)

\section{GNP per Capita}

Another relevant indicator for the sector is the GNP per capita, represented by the total production of the country divided by its number of inhabitants. According to Gremaud, Vasconcellos, and Toneto Júnior (2010), the higher the GNP per capita is, the more likely the population of a country is to live well.

Increase/decrease of the population's purchasing power affects the demand for sugarcane by-products. According to UNICA (2011 b), the higher the population's income the higher the sugar consumption, since there is an increase in the consumption of industrialised products manufactured from sugar. On the other hand, the ethanol consumption is related to an increase in the fleet of vehicles in Brazil.

According to Santander Brasil Bank (Banco Santander Brasil, 2012), the GNP per capita increased 17.5 percent a year from 2005 to 2011, on average, shifting from US\$ 4,808 to 


\section{Macrothink

US\$12,663 (Figure 4). Such a variation can be interpreted as an indicator of the increased purchasing power of the country's population.

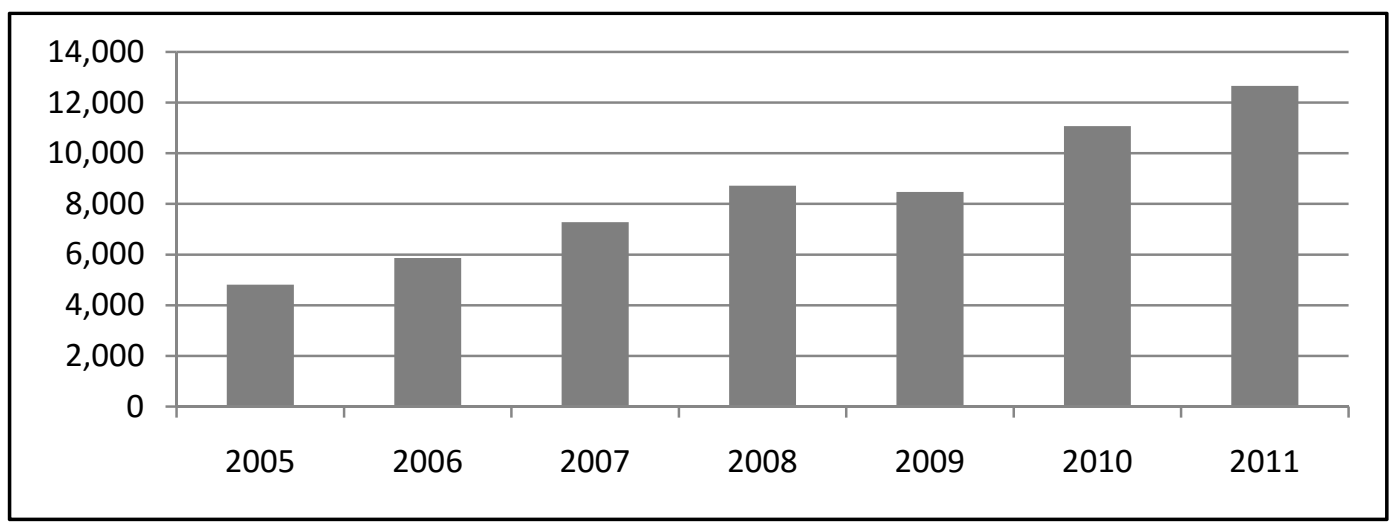

Source: Banco Santander Brasil (2012)

Figure 4. GNP per capita in Brazil (US\$)

\section{Land Availability}

As well as any other agricultural cultivation, sugarcane plantation depends on the availability of lands. This aspect and the quality of these lands for plating sugarcane are key factors for the sectorial growth in the next years. Therefore, the present work is aimed at assessing whether the availability of lands suitable for sugarcane cultivation influences the growth or decline of the production over the years.

The sum of areas considered to be of high and medium class in the Centre-Southern region is of 55,297 hectares, according to the Agro-Ecologic Zoning (Ministério da Agricultura, Pecuária e Abastecimento, 2009). Excluding the areas already cultivated from the total area suitable for sugarcane cultivation (Instituto Nacional de Pesquisas Espaciais, 2012), one can consider that the total of lands available for sugarcane cultivation shifted from 50,665 thousand/hectare in the $2005 / 06$ crop to 46,637 in the $2011 / 12$ crop, as can be seen in Figure 5 . 


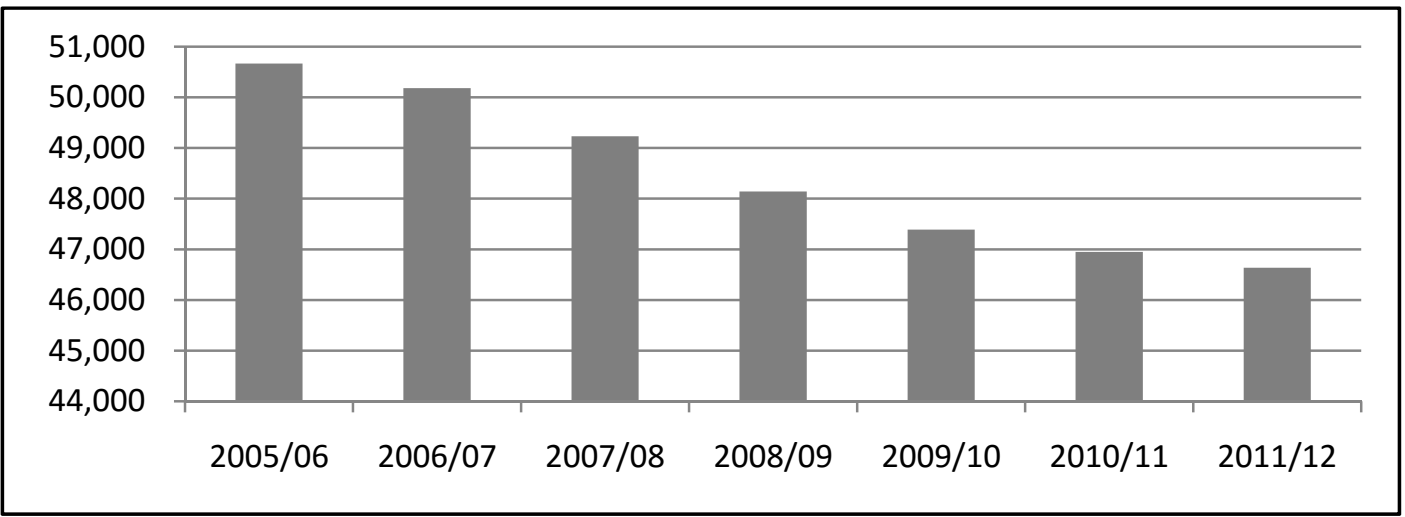

Source: Instituto Nacional de Pesquisas Espaciais (2012) and Ministério da Agricultura, Pecuária e Abastecimento (2009)

Figure 5. Availability of lands in the Centre-Southern region (ha)

\section{Economic Factors}

According to Shrivastava (1994), the economic environment comprises global, national, regional and local economies, including international trading regulations. Indicators like GNP, interest rates, employment rates, supply and demand, capital availability, among others, measure the heath of the economy.

GNP - Real Economic Growth

The sugarcane by-products tend to be more consumed in the years in which the country has a real increase in GNP than in those years in which the country has no growth.

The real growth in Brazil that occurred between 2005 and 2011 had a mean of 4.1 percent a year, according to Banco Santander Brasil (2012). This figure indicates the evolution of the Brazilian economy during that period and justifies the expectations created by the international market about the Brazil's future. The real growth in Brazil from 2005 to 2011 can be seen in Figure 6. 


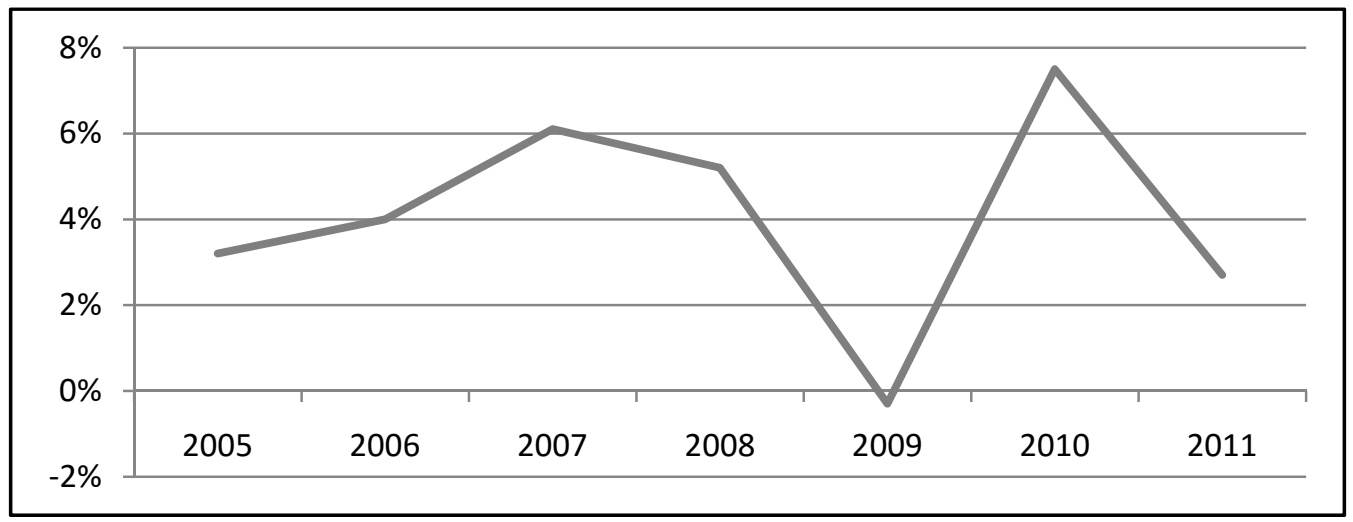

Source: Banco Santander Brasil (2012)

Figure 6. Real growth in Brazil

\section{Interest Rates}

The interest rates are among the most important economic variables. Historically, the Brazilian interest rates are one of the highest ones in the world. In 2005, for example, the Selic rate was 18 percent in the end of the year, and went on decreasing to $11 \%$ in 2011 , as can be seen in Figure 7.

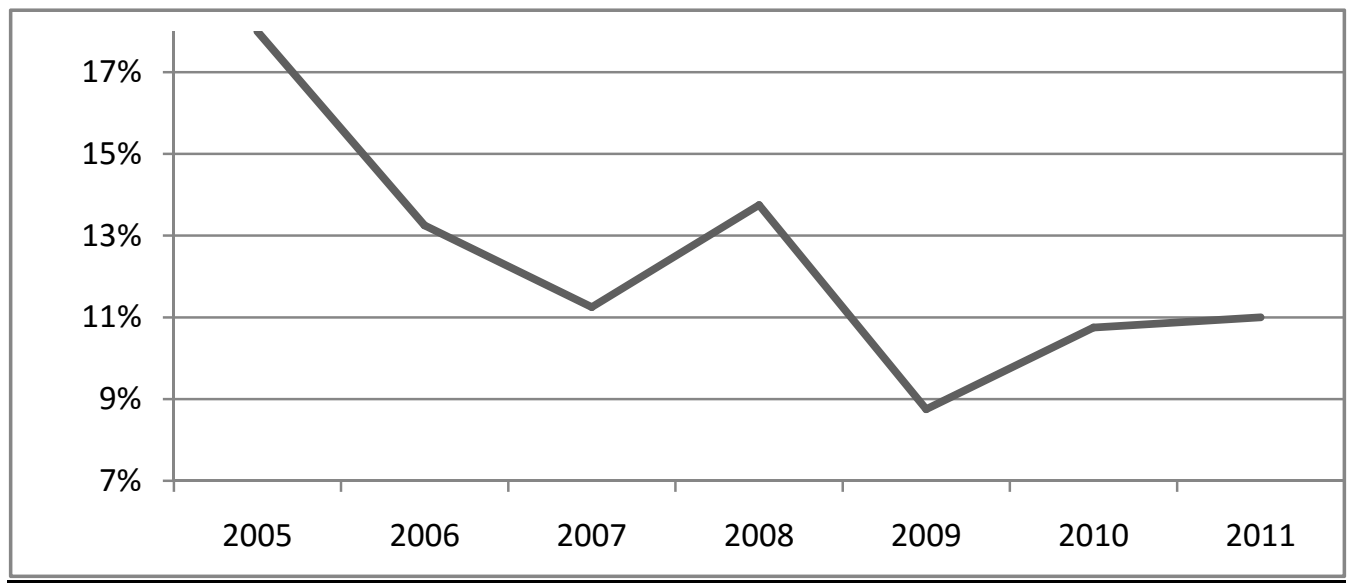

Source: Banco Santander Brasil (2012)

Figure 7. Interest-rate goal - Selic (\% per year)

\section{Credit Availability}

The financial amount of investments for expansion projects, acquisition of other units, among other growth strategies, is very high. This makes that the usage of resources from third parties become essential when executing growth projects. In this way, the capital availability becomes an important target in the analysis. 


\section{Macrothink

In addition to the investment in projects, harvesting and prices are cyclical in sugarcane industry, requiring companies strengthen their working capital structure and liquidity for periods in which revenues are practically nulls (between harvests).

With regard to projects, the BNDES (Brazilian Bank for Economic and Social Development) has played an important role as financial agent in the Brazilian sugarcane sector for expansion, cultivation, stocking, mergers and acquisitions, among others. In this way, one opted for analyzing the loans made by the companies over the years as an indicator of the availability of credit. According to the BNDES (Banco Nacional de Desenvolvimento Econômico e Social 2012), the loans to the sugarcane sector increased from US\$ 1 billion in 2006 to US\$ 3 billion in 2011, reaching the peak of US\$ 3.8 billion in 2010 (Figure 8).

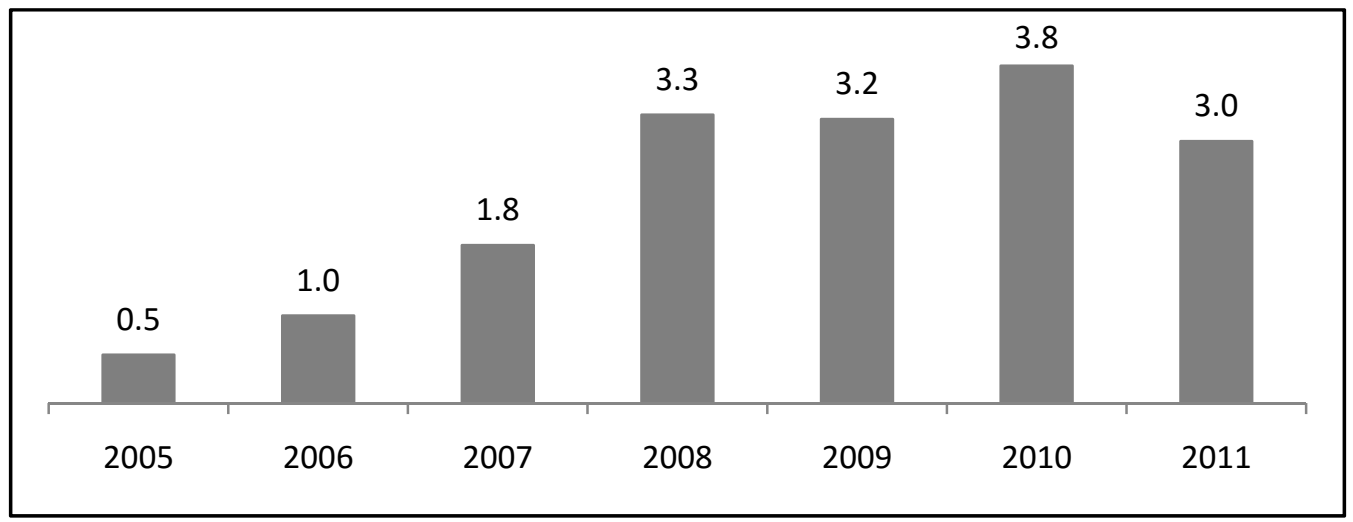

Source: BNDES (2012)

Figure 8. Credit availability measured by BNDES loans to the sugar sector (US\$ billion)

\section{Exchange Rate}

The exchange rate is a country's currency value in relation to other national currency. That is, it is the rate by which two currencies from different countries can be exchanged (Gremaud et al., 2010).

Variations in the exchange rate have influence on the economy regarding activities such as product exports, financing, and purchase of foreign equipment. In this way, exchange rate strategy is fundamental for the financial health of the companies.

According to the Banco Santander Brasil (2012), exchange rates had strong variations from 2005 to 2011. The mean exchange rate (R\$/US\$) from 2005 to 2011 can be seen in Figure 9. 


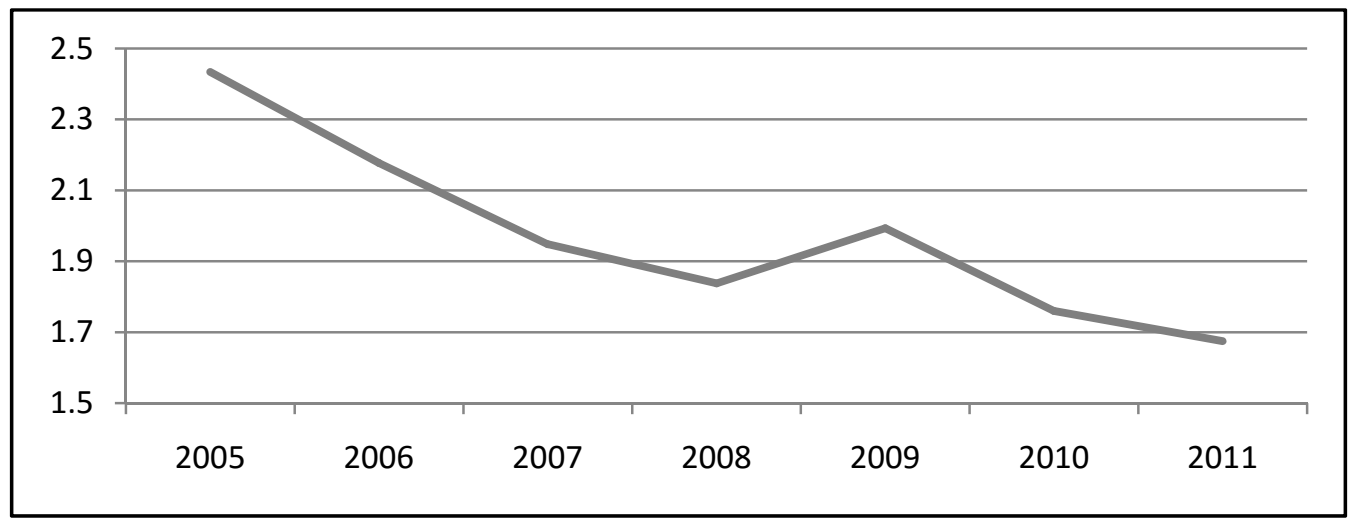

Source: Banco Santander Brasil (2012)

Figure 9. Exchange rate (US\$/R\$)

\section{Sugar Prices}

According to UNICA (2011c), more than 24 of the 33 million tons of sugar of the 2010/11 crop were exported, thus showing the importance exports have to the sugarcane companies.

According to the New York Stock Exchange ICE (Intercontinental Exchange, 2012 a), the prices of raw sugar have been rising in the past years. In 2006, the average daily quotation for the amounts of sugar negotiated corresponded to 10.04 cents/pound, whereas in 2011 this figure increased to 27.48 cents/pound (Figure 10). It is important to emphasise that there is a high negative correlation between sugar prices in the NYSE (SB\#11) and the exchange rate $\mathrm{R} \$ / \mathrm{US} \$$, since Brazil is the main price setter in the international market.

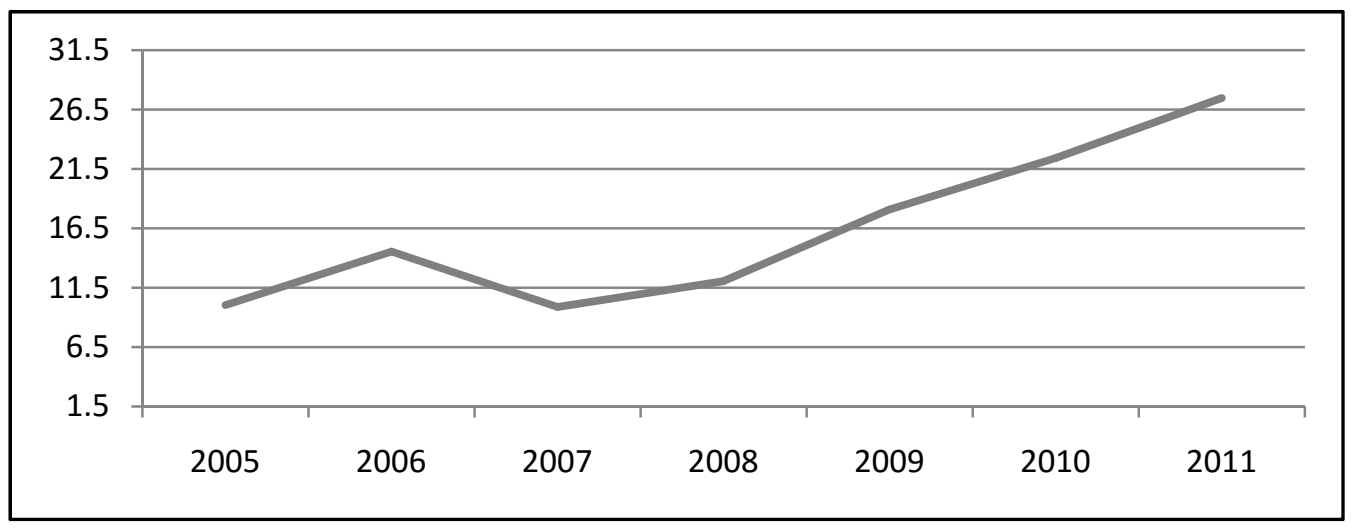

Source: NYSE ICE (2012 b)

Figure 10. Prices of the raw sugar (cents/pound) 


\section{1) Macrothink}

Oil Prices

In the sugarcane industry, the increase in oil prices is reflected on the gasoline's price, which exerts a "ceiling" price for hydrated ethanol so that the consumer can choose one or another product depending on their prices. This fact also has a direct influence on the revenues of the sugarcane mills.

According to the Banco Santander Brasil (2012), the oil price has risen in the past years. The price of the barrel of oil shifted from US\$ 55 in 2005 to US\$ 111 in 2011, exhibiting an average increase of $13 \%$ a year, as can be seen in Figure 11 .

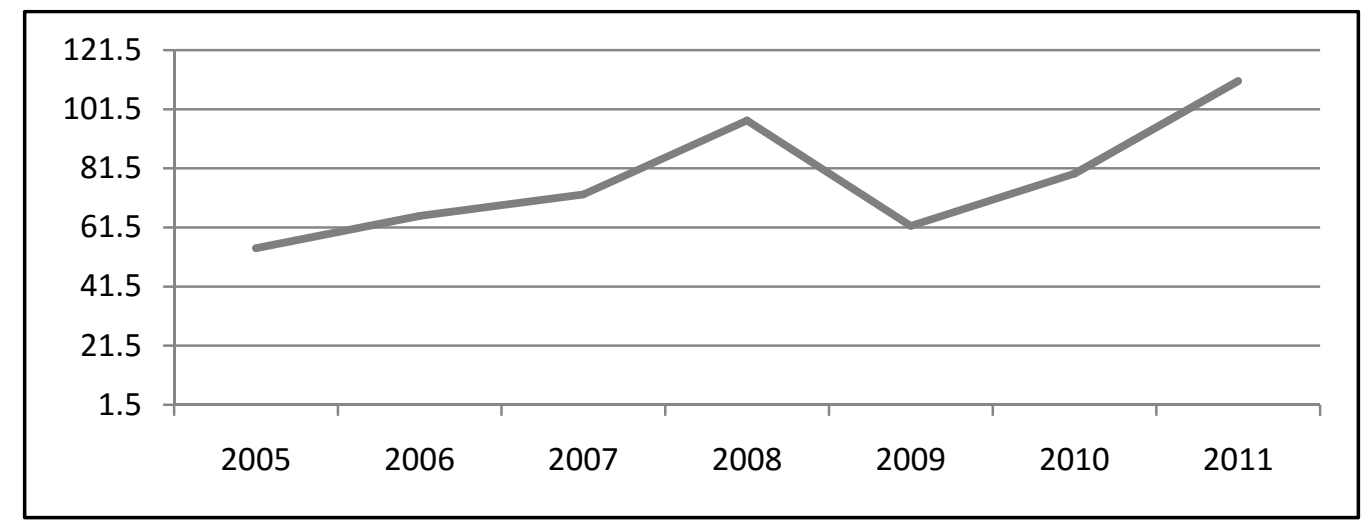

Source: Banco Santander Brasil (2012)

Figure 11. Prices of oil (US\$/barrel)

\section{Electric Energy Prices}

Sugarcane mills have been perceiving the benefits of selling their electricity and so they started to invest in projects to make the export of energy feasible. According to FG/AGRO (2011), the mills can benefit from the co-generation of energy as follows: lower volatility of the sugar and ethanol prices, EBITDA possibly representing up to half of the sugarcane business; market diversification, and aggregation of value to the mill plant.

A electricity price reference for the sector is that practiced in the auctions held by the CCEE (Electric Power Trade Centre). In the present study, the average price of the LER (reserve energy auction) in the same year was used as reference, corrected by IPCA until December 2011. In 2005, the average auction price was equivalent to US\$ 85.2 per MWh, whereas in 2011 this price was US\$ 51.4 - a drop of 40 percent, as can be seen in Figure 12. 


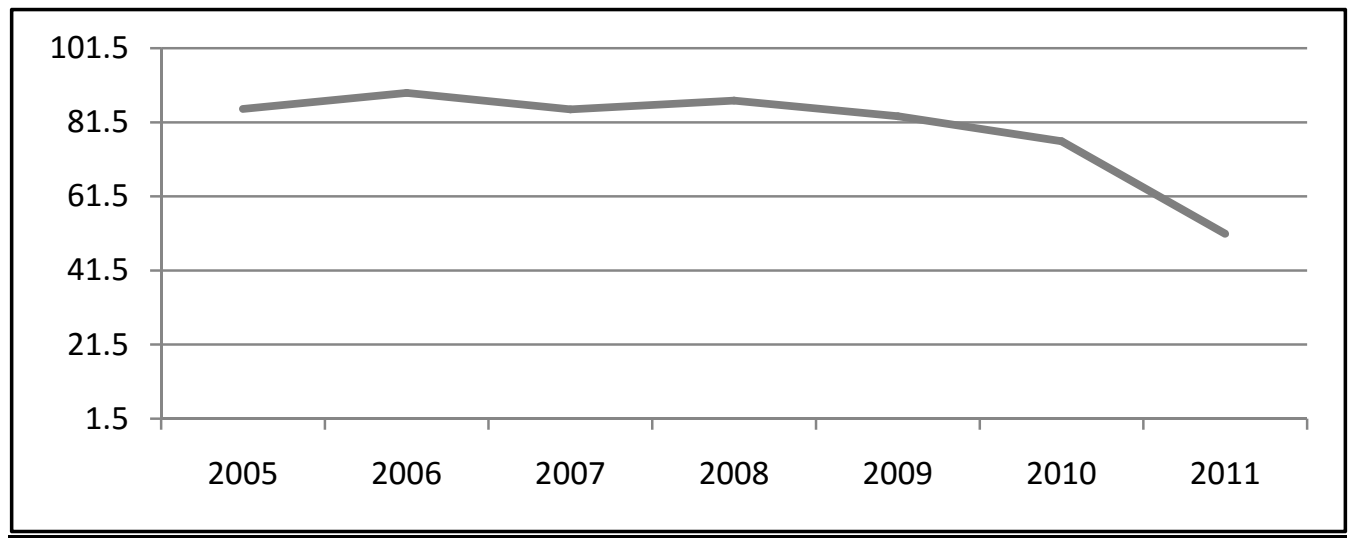

Source: Câmara de Comercialização de Energia Elétrica [CCEE] (2012)

Figure 12. Prices of electric energy (US\$/MWh)

\section{Political-Legal Factors}

The political-legal segment represents organisations who seek to influence the government, which also includes how the government influences them. The regulatory policy can change issues related to laws on taxes, competition, environment, and ruling and non-ruling philosophies, among other factors (Hitt et al., 2008).

\section{Gasoline Prices}

According to Nastari (2012), the gasoline prices have been artificially frozen by the Brazilian government in the past years in order to control inflation, which affects the financial performance of PETROBRAS and discourage the production of ethanol.

Figure 13 shows the price of gasoline $\mathrm{C}$ for consumers in the State of São Paulo. Data on prices come from National Agency for Oil, Natural Gas and Biofuel (Agência Nacional do Petróleo, Gás Natural e Bicombustíveis [ANP], 2012). One can observe a stabilisation, with variations occurring basically because of either increase or decrease in the prices of anhydrous ethanol, which corresponds to 20-25 percent of the gasoline C. 


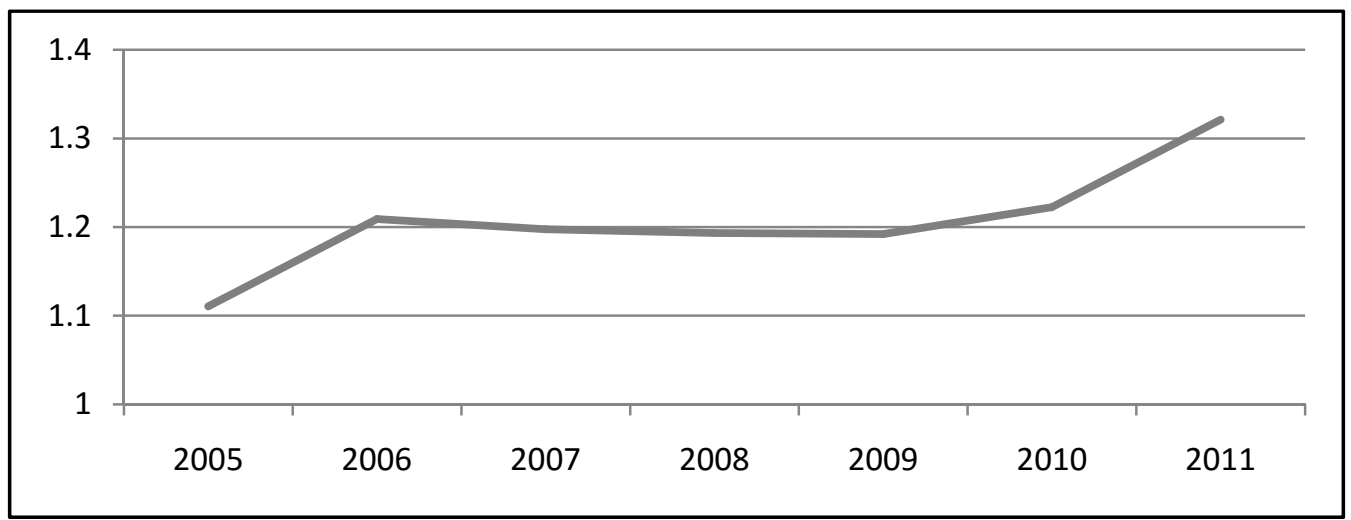

Source: ANP (2012)

Figure 13. Prices of gasoline $\mathrm{C}$ for the consumers (US\$/L)

\section{Social-Cultural Factors}

According to Pearce \& Robinson (2005), the social-cultural factors affecting a company have to do with beliefs, values, attitudes, opinions, and lifestyles of the persons in the external environment of the company, guiding the conditions and cultural, ecological, demographic, religious, educational, and ethnic changes.

\section{Agriculture Mechanisation}

The precarious working conditions among the sugarcane cutters, emission of carbon gas, and possibility of improving productivity have made the agriculture mechanisation to enter in the agenda of issues related to sugarcane sector.

According to UNICA (2011 a), the percentage of mechanical harvest in the Centre-Southern Brazil was of 34\%, reaching $80 \%$ in 2011, as can be seen in Figure 14.

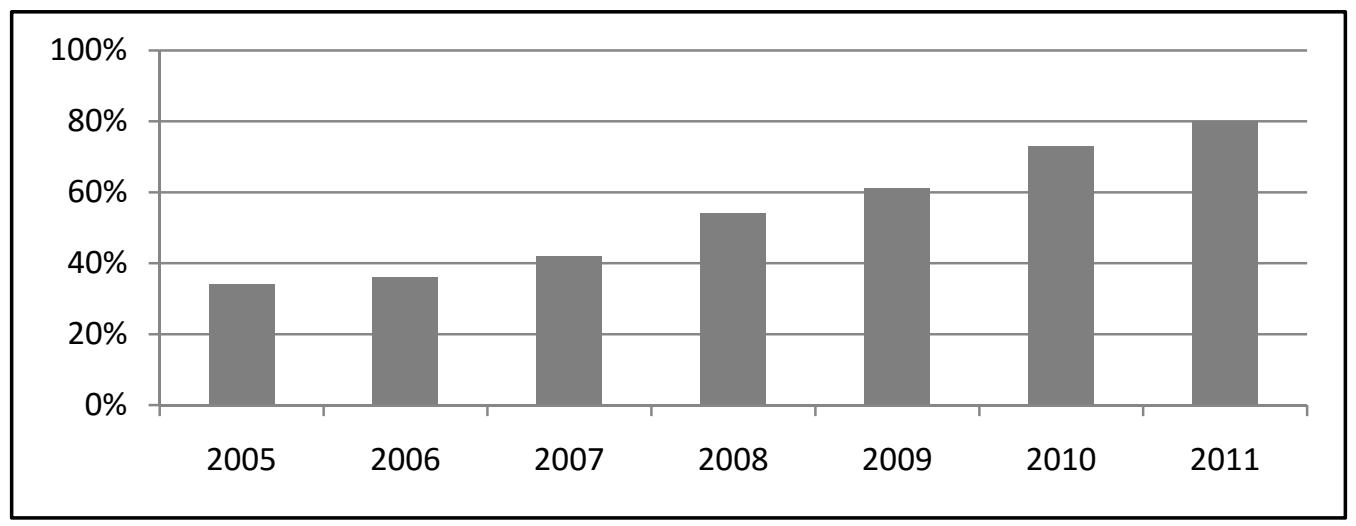

Source: ANP (2012)

Figure 14. Participation of the mechanised harvest in the Centre-Southern Brazil 


\section{1) Macrothink}

Technological Factors

The technological environment includes scientific improvements and innovations that become opportunities or threats for the organisations. The occurrence of technological innovations varies drastically from one sector to another (Wright et al., 2000).

\section{New Products}

Diversification of products in the sector of sugarcane makes the mills reduce the risks and increase their profit margins. Some of the new products are the following: cellulosic ethanol $\left(2^{\text {nd }}\right.$ generation ethanol), bioelectricity, bioplastic, and biodiesel (Neves \& Conejero, 2010).

The feasibility of producing cellulosic ethanol at a commercial scale mobilises a great number of researchers, companies, and promoting agencies in several countries in the world (João, Porto, \& Galina, 2011). By searching the Esp@cenet database, the authors found 89 patent orders between 2005 and 2010. In addition, 373 articles were also found in the bibliographic data collection for the same period. Figure 15 shows these figures, including a significant evolution in the past years.

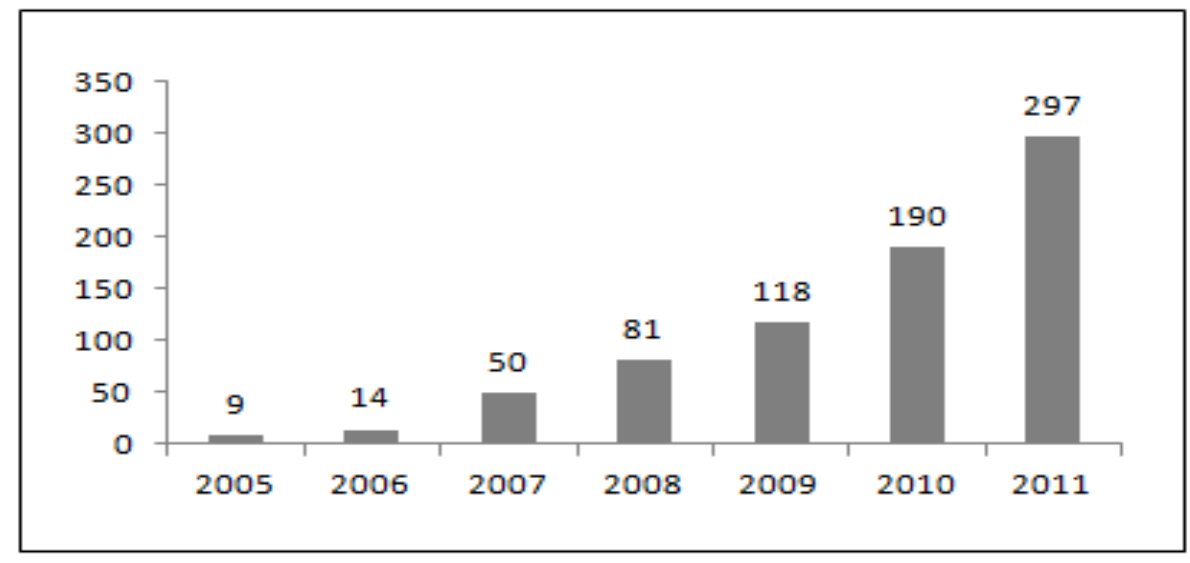

Source: João et al. (2011)

Figure 15. Patent orders and articles regarding cellulosic ethanol

\section{Productivity}

Evolution of the agriculture productivity in the sugarcane industry can occur as result of the improved use of soil, new varieties of sugarcane, cultivation methods, plague control, mechanisation, quality of equipment, labour training, among other factors. The amount of sugarcane collected per hectare is the main indicator used in the sector, thus being a reflection of these factors over time.

The average productivity per hectare in the Centre-Southern Brazil shifted from 69 tons/ha in 2001 to 74 tons/ha in 2005, reaching 80 tons/ha in 2010, thus corresponding to an annual average of 1.7 percent. In 2011, the average productivity decreased to 69 tons/ha - the same levels of 2001. 


\section{Macrothink}

Journal of Management Research

ISSN 1941-899X 2018, Vol. 10, No. 1

According to UNICA $(2011 \mathrm{c})$, this drop is mainly the result of the following: i) climate conditions, ii) lack of investment in the cultivation, iii) agriculture mechanisation, and iv) diseases and plaques. Figure 16 shows these factors.

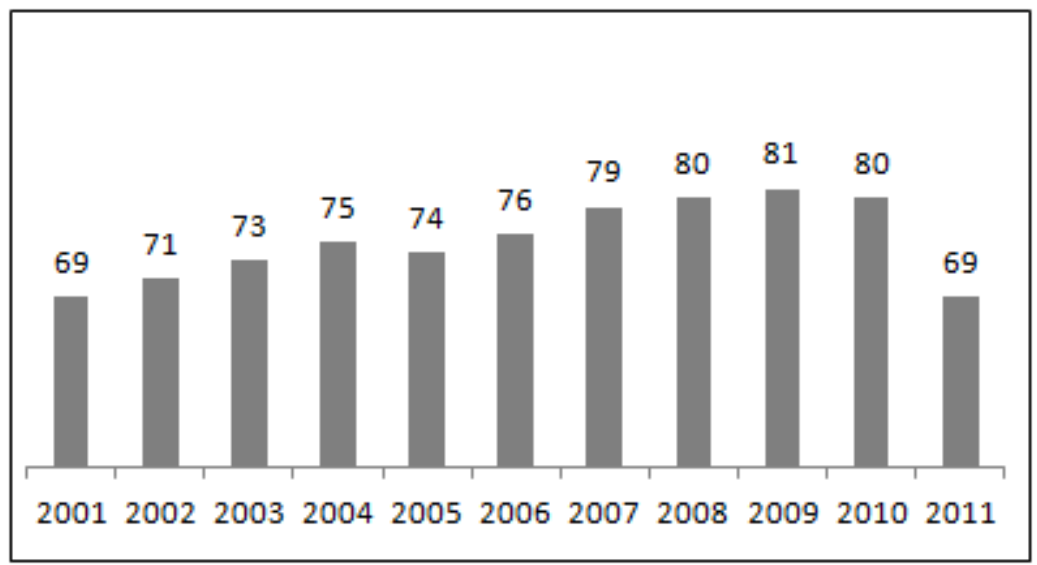

Source: Itau BBA, 2012.

Figure 16. Productivity (tons/ha)

Relationship between Macro-Environment Variables and Growth Strategies in the Sugarcane Sector

The Kolmogorov-Smirnov test indicated the use of Pearson's correlation test, which measures the degree of association between two variables from a series of observations.

In this way, the correlation among 18 variables was performed, with 14 involving macro-environment and 4 involving growth strategies. Because the aim of this work was to analyse the relationship between each macro-environmental variable and each growth strategy, Table 3 was elaborated to list the results. 
Table 3. Pearson's correlation test

\begin{tabular}{lcccc}
\hline & $\begin{array}{c}\text { Internal } \\
\text { Growth }\end{array}$ & $\begin{array}{c}\text { Horizontal } \\
\text { Integration }\end{array}$ & $\begin{array}{c}\text { Diversificati } \\
\text { on }\end{array}$ & $\begin{array}{c}\text { Vertical } \\
\text { integration }\end{array}$ \\
\hline Population & -0.474 & 0.111 & $0.864^{*}$ & 0.438 \\
GNP per capita (US\$) & -0.500 & 0.157 & $0.845^{*}$ & 0.462 \\
Land availability & 0.382 & -0.136 & $-0.837^{*}$ & -0.503 \\
Real growth rate & 0.341 & $0.800^{*}$ & -0.006 & 0.517 \\
SELIC Interest rates & 0.016 & -0.251 & -0.664 & -0.430 \\
Capital availability & -0.093 & 0.287 & 0.677 & 0.699 \\
Sugar prices & -0.753 & -0.195 & 0.702 & 0.030 \\
Oil prices & -0.304 & 0.093 & 0.541 & 0.558 \\
Electric energy prices & $0.42^{*}$ & 0.169 & $-0.772^{*}$ & 0.047 \\
Exchange rate & 0.62 & -0.378 & $-0.762^{*}$ & -0.727 \\
Gasoline prices & -0.77 & -0.010 & 0.657 & 0.288 \\
Mechanised crop & -0.563 & 0.055 & $0.844^{*}$ & 0.365 \\
New products & -0.696 & -0.015 & $0.860^{*}$ & 0.229 \\
Productivity & -0.406 & 0.155 & $0.817^{*}$ & 0.542 \\
& $*$ Significant at 5\% & & \\
\hline
\end{tabular}

The strategy of internal growth, considering a 5-percent significance, showed a positive correlation of 0.842 with variable "electric energy prices". Therefore, one can understand internal growth strategies are more likely to occur in the periods of increase in the electric energy prices. This finding corroborates the concept that good prices of electric energy have been a strong attractive factor among sugarcane mills in terms of internal growth, mainly the investment for new products, both brownfield or greenfield filed ones.

An example of internal growth influenced by the electric energy price is the case of the Usina Jalles Machado, a traditional sugarcane company, whose seat is located in the city of Goianésia, State of Goiás. In 2007, the company initiated the construction of a greenfield plant in the same city. One of the main factors leading to this unit was the price of electricity at that time. With that entrepreneurship, the sugarcane mill managed to sell its electricity in the $8^{\text {th }}$ new energy auction in 2009 for approximately $72.5 \mathrm{US} \$ / \mathrm{MWh}$, a price much higher than that practiced today.

By analysing the relationships between horizontal integration and macro-environment variables, one can observe that the only variable with relevant level of significance as the variable "real growth rate", with a correlation of 0.800 . The idea that Brazilian economy is growing and the demand for sugarcane by-products should also follow this trend may have led the mills to acquire similar companies operating at the same level in the production chain in order to increase the supply of sugar and ethanol.

The acquisition of Mandú Mill by Açúcar Guarani in 2010 marked the increase in the production capacity of the latter. In fact, Açucar Guarani company expanded its participation in the sector, thus keeping itself among the five largest producers of sugarcane in the country in that time. 
Among the growth strategies, diversification is that presenting the highest amount of significant relationships with macro-environment variables. One can observed positive correlations with population (0.864), GNP per capita (0.845), mechanised harvest $(0.844)$, new products $(0.860)$, and productivity $(0.817)$ on the one hand, and negative correlations with land availability $(-0.837)$, electric energy prices $(-0.722)$, and exchange rate $(-0.762)$ on the other hand.

In the periods in which there were changes in the variables with strong positive correlation, it was observed a similar behaviour in the number of occurrences of diversification strategies, that is, when one increases or decreases the other follows the same trend. Nevertheless, the variables with negative correlation show an opposite trend, that is, when a variable increases the occurrence of strategy decreases, and vice-versa.

A practical example of diversification is the strategic alliance formed between ETH Bionergia (traditional sugarcane group) and Amyris Inc. (leading company in the sector of renewable fuels and chemical products). The latter company, aiming to enter the sector to study and expand the development of sugarcane by-products, probably analysed the external environment and decided that it was a good moment to make such investment.

Finally, the results of the Pearson's correlation show that there is no strong association between vertical integration and the macro-environmental variables studied.

It was demonstrated that each type of growth strategy is related to a specific type of variable, which never repeats, except in the case of diversification. That is, sugar prices, new products and electric energy prices had correlations with internal growth (although only the last variable had a 5-percent significance), whereas real growth rate was correlated with horizontal integration. None of these macro-environmental variables repeated in other growth strategies. The only exception was the diversification strategy, which presented correlations with eight variables (as described earlier), in which five are exclusive to this type of strategy, namely: population, GNP per capita, land availability, mechanised harvest, and productivity.

\section{Conclusions}

The way in which each company grows can directly influence the growth of the sector. Therefore, the present work sought to identify the relationship between macro-environmental variables and the occurrence of each growth strategy adopted by sugarcane industry companies. For doing so, the environmental circumstances in which growth strategies occur were assessed: internal growth, horizontal integration, diversification, and vertical integration.

Each macro-environmental variable (i.e. demographic, economic, political, social-cultural, and technological) has a determined influence on the sector's behaviour. Changes in these variables also alter the behaviour of the sugarcane sector companies, making them adopt different strategies in order to take advantage of the opportunities and avoid threats.

Internal growth has shown a significant correlation with the variable "electric energy prices" only. This can be explained by the fact that in the recent years most greenfield units are 
aimed at co-generation for exporting electricity, thus making this variable an important item for the study of the feasibility of project.

With regard to the horizontal integration, one can observe that the only variable presenting a relevant significance level was the real growth worth rate. Sugarcane mills may have opted for performing horizontal integration by the fact that they perceived a growth in the national economy and consequent increase in the demand for their products.

In addition to the macro-environmental variables of the sugarcane sector identified during the bibliographic survey, it is important to add that mergers and acquisitions are other reasons. Although they were not addressed in the present study, they can influence the operational and financial synergy (scale and financial economies), accelerated sectorial growth, market power (monopoly and competitive positioning), managerial efficiency (maximisation of managerial utility), fiscal economy, strategic re-alignment, managerial pride, and over-valorisation of shares (DePamphilis, 2001; Málaga, 2007).

The information on growth strategies used by companies was an important limitation for the present study. In fact, many transactions and agreements are subjective and non-formal, thus not enabling these to be mapped.

The ideal approach for this study would be to assess each strategy in the year in which the decision on it was made rather than when the strategy was implemented. In this way, it would be possible to analyse the relationship between macro-environment and decision-making, but the difficult in mapping the period in which the decision was made would also make this study unfeasible.

In view of this, it is suggested that further studies are conducted in order to deepen the knowledge on the theme. Some studies might be performed from the present one so that the following issues could be better understood: i) how the internal environment of a company influences the growth strategies, ii) prediction of strategic growth movements for subsequent the years, and iii) time elapsed from the choice of strategy and its implementation and the external environment at that moment.

\section{References}

Agência Nacional do Petróleo, Gás Natural e Bicombustíveis. (2012). Preços da gasolina C ao consumidor em São Paulo. Recuperado de http://www.anp.gov.br.

Banco Santander Brasil. (2012). Histórico e projeções econômicas do Brasil. São Paulo, SP: Banco Santander do Brasil.

Banco Nacional de Desenvolvimento Econômico e Social. (2012). Atraindo financiamento e investimentos para a indústria sucroenergética - o papel do BNDES. Trabalho apresentado no Oitavo F.O Licht Sugar \& Ethanol Brazil. São Paulo, SP.

Câmara de Comercialização de Energia Elétrica. (2012). Preços históricos dos leilões de energia elétrica. Recuperado de http://www.ccee.org.br 


\section{Macrothink}

Journal of Management Research

ISSN 1941-899X

2018, Vol. 10, No. 1

Canaplan. (2012). Setor de cana-de-açúcar no Brasil: Situação atual e perspectivas para a retomada do crescimento. Trabalho apresentado no Décimo Seminário Guarani, São Paulo, SP.

Companhia Nacional de Abastecimento. (2012). Acompanhamento da safra brasileira de cana-de-açúcar - primeiro levantamento. Recuperado de http://www.conab.gov.br

DePamphilis, D. M. (2001). Mergers, acquisitions, and other restructuring activities. San Diego, CA: Academic Press.

FG/AGRO. (2011). Cogeração no contexto do setor elétrico brasileiro. Trabalho apresentado no Nono Seminário Guarani: Cenários e perspectivas para os mercados de açúcar, etanol e energia safra 2011/12, São Paulo, SP.

Food and Agricultural Organization of the United Nations. (2012). Produção de cana-de-açúcar em 2010. Recuperado de http://faostat.fao.org/

Fundo Monetário Internacional. (2012). PIB per capita brasileiro de 2005 a 2020. Recuperado de http://www.imf.org

Gremaud, A., Vasconcellos, M., \& Toneto Júnior, R. (2012). Economia brasileira contemporânea. São Paulo, SP: Atlas.

Gryubisich, J. (2012, janeiro 6). Setor de bioenergia precisa de definição de políticas públicas e desoneração tributária. Folha de S. Paulo. Recuperado de http://www1.folha.uol.com.br/fsp/mercado/18510-setor-de-bioenergia-precisa-de-definicao-d e-politicas-publicas-e-desoneracao-tributaria.shtml

Hitt, M., Ireland, R., \& Hoskisson, R. (2008). Administração estratégica: Competitividade e globalização. São Paulo, SP: Cengage Learning.

Instituto Nacional de Pesquisas Espaciais. (2012). Canasat: Mapa do cultivo da cana-de-açúcar no centro-sul da safra 2005/06 até a safra 2011/12. Recuperado de http://www.dsr.inpe.br/laf/canasat/

Intercontinental Exchange. (2012a). Preços de fechamento do pregão de 18/05/2012. 2012. Recuperado de http://www.theice.com

Intercontinental Exchange. (2012b). Média dos preços diários de fechamento ponderados pelos volumes de negociações de 2005 a 2011. Recuperado de http://www.theice.com

Itaú BBA. (2012). Desafios para o investimento em novas usinas de etanol no Brasil. Trabalho apresentado no Seminário Desafios para o investimento em novas usinas de etanol no Brasil. Rio de Janeiro, RJ.

Jank, M. (2011, abril 4). Etanol: O gargalo. O Globo. Recuperado de http://oglobo.globo.com/ece_incoming/etanol-gargalo-2901616 
João, I., Porto, G., \& Galina, S. (2011). A posição do Brasil na corrida pelo etanol celulósico: Mensuração por indicadores C\&T e programas de P\&D. Revista Brasileira de Inovação, 11(1), 105-136. https://doi.org/10.20396/rbi.v11i1.8649028

Kotler, P., \& Keller, K. (2006). Administração de marketing. São Paulo, SP: Pearson Education do Brasil.

Málaga, F. K. (2007). Estudo do risco sistêmico das empresas resultantes de fusões e aquisições e as expectativas dos investidores e dos gestores (Tese de doutorado não publicada). Universidade de São Paulo, São Paulo, SP.

Ministério da Agricultura, Pecuária e Abastecimento. Empresa Brasileira de Pesquisa Agropecuária. (2009). Zoneamento acroecológico da cana-de-açúcar. Rio de Janeiro, RJ: EMBRAPA.

Nastari, P. (2012, março 2). Contenção de preço de combustíveis traz mais perdas e distorções que benefícios. Folha de $S$. Paulo. Recuperado de http://www1.folha.uol.com.br/fsp/mercado/28818-contencao-de-preco-de-combustiveis-trazmais-perdas-e-distorcoes-que-beneficios.shtml

Neves, M., \& Conejero, M. (2010). Estratégias para a cana no Brasil. São Paulo, SP: Atlas.

Nyko, D., Faria, J. L. G., Milanez, A. Y., Castro, N. J., Brandão, R., \& Dantas, G. A. (2011). Determinantes do baixo aproveitamento do potencial elétrico do setor sucroenergético: Uma pesquisa de campo. Rio de Janeiro, RJ: BNDES.

Pearce, J., \& Robinson, R. (2005). Strategic management: Formulation, implementation, and control. New York, NY: McGraw-Hill/Irwin.

ProCana. (2012). Anuário da cana 2012. São Paulo, SP: ProCana.

Shrivastava, P. (1994). Strategic management: Concepts and practices. Mason, OH: South-Western.

União da Indústria da Cana-de-Açúcar. (2011a). Concentração da plantação da cana-de-açúcar no Brasil. Recuperado de http://www.unica.com.br/

União da Indústria da Cana-de-Açúcar. (2011b). Ethanol and the future of biofuels. São Paulo, SP: UNICA.

União da Indústria da Cana-de-Açúcar. (2011c). Estimativa da safra 2012/2013. São Paulo, SP, UNICA.

United States Department of Agriculture. (2012). Mercado mundial de açúcar na safra 2010/11. Recuperado de http://www.usda.gov/

Wright, P., Kroll, M., \& Parnell, J. (2002). Administração estratégica. São Paulo, SP: Atlas.

Zafalon, M. (2011, julho 27). Consolidação do setor ainda não reflete novos investimentos. Folha de S. Paulo. $\quad$ Recuperado de http://www1.folha.uol.com.br/fsp/mercado/me2707201106.htm 